\title{
The Writing Techniques Used in Presentation of Love Theme in Some of Muyaka's Poems (1979)
}

\author{
Ogongi Ruth Atieno*, Oluoch Stephen, Karithi Francis \\ Department of Language and Literature, Kisii University, Kisii, Kenya \\ Email address: \\ ruthogongi@gmail.com (O. R. Atieno), yahuma1976@yahoo.com (O. Stephen), kariithifranck2000@yahoo.com (K. Francis) \\ ${ }^{*}$ Corresponding author
}

\section{To cite this article:}

Ogongi Ruth Atieno, Oluoch Stephen, Karithi Francis. The Writing Techniques Used in Presentation of Love Theme in Some of Muyaka's Poems (1979). International Journal of Literature and Arts. Vol. 8, No. 4, 2020, pp. 191-195. doi: 10.11648/j.ijla.20200804.13

Received: February 9, 2020; Accepted: February 25, 2020; Published: May 12, 2020

\begin{abstract}
Poetry is one of the genres in Swahili literature; it is categorized in written literature. Poetry is composed and presented to the audience however; each author has his way of communicating his messages which promote themes. This research is on The writing techniques used in presentation of love themes in some of Muyaka's Poems. Although there are studies that have been carried out concerning the elaboration of themes by researchers, there was still a shortage of research done basing on The writing techniques used in presentation of love themes in some of Muyaka's Poems. The main objective is to analyse the writing techniques used in presentation of love theme in some of Muyaka's poems in Muyaka's poetry book. The research is conducted in Muyaka's poetry. The selection of this poetic book was done using purposive technique. This is a library based research hence the technique used to collect the data is the document analysis technique. Data is analyzed descriptively based on the prisms. The main purpose of this paper is to cover the gap that has been left without being researched on which is writing techniques used in presentation of love themes in some of Muyaka's Poems. The research is guided by two theories; New Critism that emphasizes on the close reading analysis and Stylistic theory that emphasizes on how language can be used in a literally work. The method mainly involved the use of observation and reading. The data is analyzed based on the prisms of the two theories. The findings indicated that the writing techniques used in presentation of love themes are used effectively in Swahili poetry, the writing techniques used include Similes, Imagery, Hyperbole, Repetition, Rhetorical questions metaphors, Sayings, and Parables, the study revealed that the techniques used in the presentation of love themes are appropriate hence they are likely to make the language interesting, to enable the reader think, encourage community members and it makes communication effective. This paper will help a common man to be aware of how love themes can be presented in the African society, the countries that use Swahili language will give guidance to their scholars on poetry, also this work will be a good reference material to other research works.
\end{abstract}

Keywords: Poems, Themes, Love, Writing Techniques

\section{Introduction}

Many scholars have given several views under the explanation of the word theme, Scholars such as [1-3]. Literally theme is the central topic or idea explored in a text, however theme are usually expressed through the characters, actions, thoughts and even words. This paper basically concentrated on love themes, themes are sayed to be generally universal in nature and they tent to relate the conditions and way of life of human beings.

Studies have been done on poetry known as Ushairi in Swahili language. Massamba [4] explains that any narrative that qualifies to be called a poem, it should have same stanza, the tone should be meditative, reflective and creates feelings. Nzuiki [5] did a research on poetry where he used Kithaka wa Mberia's poems written in his books called Bara Jingine [2001] and Mchezo wa Karata [1997], Nzuki concentrated on how language and themes work together in this two poetic books.

Ngolo [6] in his research on Said A Muhamed poems, where he picked on his three poetic books which are Sikate Tamaa [1980], Kina cha Maisha [1984] and Jicho la Ndani [2002] his study based on the changes in writing structures where his study revealed that some poems in Sikate Tamaa 
book have been written using the recent structures and formats. His study differs with my paper in that it concentrates on how different writing techniques have been used to develop love theme in some of Muyaka's poems.

\section{The History of Swahili Poetry}

Swahili poetry has a long and rich history among the Swahili people of the East African coast, predating the emergence of other literary genres by several centuries. Central to this poetic tradition was the utenzi which is usually translated as epic or struggle. These poetic works characteristically were quite lengthy and, in the earliest extant. The history of Swahili poetry is explained in different stages as follows.

Before colonization [1890]. This is the period before the coming of colonizers, this period is said to go hand in hand with the oral literature of Swahili people, the oral literature was passed from one person to the other through the word of mouth. During this time Swahili poetry was owned by the Swahili community.

The second stage is after colonization [1890-1945]. This period is called utasa in Swahili, it's called so because very few poems were composed, the main reason was, the colonizers interfered with the peace that was in the coastal region and this disorganized the way of living of Swahili people.

The third period is the period when Africans started to rule themselves [1945-1970]. During this period people started going to school and started learning the writing skills. The Swahili poets that came out this period included Kaluta Amri Abedi, Shaaban Bin Robert, Mathias Mnyampala na Snow White Akilimali.

The last stage that explains the history of Swahili poetry is Neocolonism [After 1970]. During this period groups came up with rules of composing Swahili poems and how to analyses the poems effectively.

Muyaka being one of Swahili poets, he composed several Swahili poems that touched on the people's way of life, religion and also culture. He composed basing on different themes that portrayed the life of Swahili people. This paper comprises of some of Muyaka's Swahili poems that are been translated into English.

\section{Methods}

A favorable design was used to collect data where by document analysis technique was used. A case study research design was used in this paper. A case study research design is an intensive, descriptive and holistic analysis of single entity and the bounded case. The purpose of this design is to study a single entity in depth in order to gain insight into a larger case, this is according to Oso and Onen [7]. In this case smaller sample was used where few poems were picked and analyzed.

\section{Procedures}

The data was collected within three weeks. The selected poetry book was read by the researcher critically by going through a poem after the other, this enabled the researcher to come across poems that tend to portray love themes through different writing techniques used. The procedure is referred to as document analysis.

\section{Data Analysis}

Data analysis is whatever a researcher has observed, heard and read through his/her interaction with and observing research participants and documents in order to solve a research problem. It is the process of organizing data into meaningful and useful information that helps a researcher to answer the research questions. Data analysis is used in all forms of studies where data collection is carried out such as in business, social science and others. Data is analyzed in different ways, in this paper the theme of love made the main idea hence the writing techniques used to develop it was picked and they were made to make the object of analysis. The descriptive analysis is used to explain the data found. The writing techniques in the poems are analyzed separately they included; rhetorical questions, hyperboles, similes, imageries, repetition and metaphors respectively.

\section{Results and Discussions}

The Writing Techniques used in Presentation of Love Theme in some of Muyaka's Poems (1979).

\subsection{Rhetorical Questions}

Leech explains that rhetorical questions are questions that do not expect any answer. He says that rhetoric questions are words that are used to trigger somebodies way of thinking to try to rise up questions.

Habwe says that rhetorical questions are used by the speakers to stir up people to think in a wider perspective, this is as per reference [9]. His views are further developed by Goody who maintains that rhetorical questions are used as a way of making the language interesting and through his the message that is being portrayed satisfies people [10].

In this paper rhetorical questions as one of the writing technique has been used to develop the theme of love in some of Muyaka's poems. An example of poems with rhetorical questions are shown below:

The poem you will stay at home dear.

Give me Sulphur and a little vitriol.

So that the charming lady might put them on the fatal spear.

There she is nobody wants her. Repent! You changeling;

You haven't got even a rag?, let alone a cotton wrap.

I told you "don't do it you replied I will".

O you woman, "don't go "You said "I must".

Today you are shrunk in misery, clinging to your bed.

Tomorrow your friends are having a get -together, what are 
you going to wear?

The above poem portray the love theme, Muyaka is not happy because his wife goes for an outing with her friends without his permission, also he does not want her to stay away from the homestead because of the love feelings he has to his wife. Muyaka by saying the above statements, he tents to portrays the theme of love. Words like which dress will you put on or wear? does not require an answer.

Another poem that has rhetorical questions is on page (304) of the poetry book having a title "On temporary love" the poem goes like this;

Love was so intense when it first begun

We thought it would last forever, nothing could destroy it.

Alas now it is topsy-turvy, changing its nature

What can be left when a mere half ounce of love grows less?

The poet has used rhetorical questions to portray love theme, he asks himself What can be left when a mere half ounce of love grows less? to him he argues that love does not come to an end so he expects love to be there forever and nothing should stop love from existing.

The poem has got love themes and the theme has come out by use of the rhetorical questions Muyaka is asking himself. All this is in the name of love.

\subsection{Hyperbole}

Wamitila in his views explains that hyperboles are used by the artists to give the characters that are more exaggerative. The purpose of using hyperboles is to make the ideas to come out in an open way and through this the reader will be able to think critically about the idea [11]. On the other hand Arege, [12] says that hyperbole is a way of using words by adding "salt" to emphasize on certain ideas or to praise something or somebody. An example of a hyperbole is when you say the city was full to the brim, he carried millions on his head and more others.

The hyperboles writing technique is used in the poems of Muyaka to portray or develop on the love theme as seen in the following poem.

Longing to see his beloved

I wish I were a little bird who could fly to where you are,

And we'd be by ourselves so that we could chase away this sadness

So that we could communicate our innermost feelings, I to you

I long to come to you but approval is not yet given

The signs of longing are very clear to you

You occupy my mind so much, can no longer bear it.

That's why I am so unhappy and disturbed

I long to come to you but approval is not yet given.

The hyperbole is used on line two on the second stanza where somebody cannot get inside somebodies heart. This technique has been used to develop the love theme in that it has shown the deep love that somebody has for the other.

\subsection{Metaphor}

Kahigi in his swahili paper about language of children explains a metaphor as a simile that is used to compare one item with the other whose characters are the same. As in reference [14]. Myers and Simms [15] says that the word metaphor comes from a Greek word that means to transfer or to move from one end to the other. From the explanation of this scholar we can say metaphor is a word that is used to compare two different things that bear the same characters.

Mbuvi [16] maintains that metaphor is the phrase used in comparison of one thing and the other that has the same characters. Richard says that metaphor is to compare two things without using the word "like".

Muyaka has used metaphors as writing technique to portray love theme in his poetry. This is seen in the following poem;

Love is bewitching when intense it is utterly ruinous.

Love is a burden that presses heavily.

Love is foolishly blind, unable to see any defect.

Love fears neither a curse nor slander!

In the above poem Muyaka believes that, when love increase it is only seen in two people who are in love, so he has emphasized on how love is by use of metaphors, this has brought out love theme.

\subsection{Similes}

Swahili dictionary abbreviated as TUKI states that similes are words which are used to compare two things [13]. Senkoro says that similes are words used to compare two or more things by use of words such as "like", "as" and so on, example you can say Daudi is as black as charcoal, so in this case the color of Daudi has been compared to that of charcoal, as reference [17].

The comparison is used to show thing like behavior, praises, way of living and so on. Similes have been used to portray love themes in that Muyaka has used several similes to praise his lover or he has used similes to give names to his lover as a way of showing love to her. This is shown in this poem on page 322 , poem which bears a title Say so if you don't want me;

It's so surprising in a fine and attractive woman.

When you see her at home it's like a pearl in its shell.

Except that she is impossible when you want to make up to her.

She is full of surprises. Tell me what is that that you really don't want.

\subsection{Imagery}

Imagery in poetry is the use of figurative language to trigger or evoke a reader. Many poets use imageries as a way of making his readers think critically and also have an internal and external feelings and emotions.

Other scholars maintain that imagery is a picture that comes in the readers mind when he or she reads across the poem. They say that only when you read keenly that's when you get the image the poet is trying to put across or portray 
this is accordind to Ndungo and Wafula [1].

Muyaka has used imagery to portray themes of love in his poems such as I cannot sleep on page 200 that goes;

My clever messenger, today I wish to send you on an errand

Go to the black-eyed dove of rank respectability

Deliver to her my message

I swear to the Generous one, I can't get any sleep.

When you come near her, my special dove

Approach her with a pleading voice, falling on your knees

Telling her all that I feel in my heart

My eyes can hardly see for lack of sleep.

Muyaka has used an imagery of sleep in love, he says that love is as sweet as sleep. He continues to say that he does not sleep because of the love he is being shown by his lover.

Love has made him to live in fear because every time he thinks about his lover. In the $1^{\text {st }}$ stanza the word "basiri" in Swahili has been used to draw a picture of a cleaver person or somebody who is capable of thinking well and who knows many things.

\subsection{Repetition}

The term repetition has been explained with some scholars, an example Wamitila explains that repetition is a word used to illustrate the aspect of repeating of words, sounds or even sentences,[18]. Kuhenga [19] says that repetition is the kind of expression where by the speaker accidentally or not by accidentally repeats words to emphasize on something, the purpose of repeating words is to stress on that particular word for a reader to be keen on the message that is being portrayed.

In my view I may say that repetition is a way of emphasizing on a word to put more stress for a reader to contemplate. Repetition as one of the writing technique, Muyaka has used it to portray love theme in his poetry work. An example of repetition is seen in the following poem

$\mathrm{OA}$

Oa if you are the marrying type and used to married life,

Oa, with sharp eyes and pupils that are wide open

$\mathrm{Oa}$, wish yourself in deep water which is as pure as milk,

$\mathrm{Oa}$, This is marriage, who goes through life without marrying?

Stanza 1

Oa, you are the swimmer used to swimming,

Oa, do not shut your eyes, open them wide,

Oa, so that you might beget children, just as you were begotten.

$\mathrm{Oa}$, this is marriage, who goes through life without marrying.

Stanza 2

This poem explains that somebody should only marry that person he or she loves most, love has been portrayed by the repetition of this words "Oa" [marry] and the theme in the poem is love.

\section{Conclusion}

The purpose of this paper is to analyze the writing techniques used in the presentation of love theme in some of Muyaka's poems [1979] The findings indicate that the writing techniques have a wider opportunity in the development of love themes in Muyaka's poems.

This paper managed to analyze some of the writing techniques used, they included;- rhetorical questions, here in most cases the statements said does not require any answer, hyperbobe where too much exaggeration is used to an individual either in favors of something and so on.

This paper concluded that the writing techniques used in Muyaka's Swahili poems are only used to make the poems more interesting and to be well understood by the readers of different caliber.

\section{References}

[1] Ndungo, C. M. na RM. Wafula. (1993). Nadharia ya Fasihi Simulizi: Lecture series University of Nairobi.

[2] Walibora, K. (2008). Malenga wa Karne Mpya. Nairobi: Phoenix Publishers Ltd.

[3] Mbatia (2001), Kamusi ya fasihi, Standard Textbook, Nairobi.

[4] Massamba, D (1983). Utunzi wa Ushairi wa Kiswahili: Fasihi. Makala za Semina ya Waandishi wa Kiswahili. Dar es Salaam.

[5] Nzuki. P. K. (2003). Mwingiliaino wa fani na maudhui katika ushairi wa kithaka wa mberia, tasnifu ya uzamili, Chuo Kikuu cha Nairobi (haijachapishwa).

[6] Ngolo, E. (2004). Mabadiliko ya kimtindo katika ushairi wa Said A. Mohamed, UON, (tasnifu ya uzamili ambayo haijachapishwa).

[7] Oso, W. Y. and Onen, D. (2005). Writing Research Proposal and Report: A Handbook for beginning researchers. Nairobi: Jomo Kenyatta Foundation.

[8] Leech, G. (1969). A Linguistic Guide to Poetry. London: Longman.

[9] Habwe, J. (1999). 'Discourse Analysis of Swahili Political Speeches'. Ph. D Thesis, University of Nairobi (Unpublished).

[10] Goody, E. N. (1978). Towards a Theory of Questions: Questions and Politeness Strategies in Social Interactions. Cambridge: Cambridge University Press.

[11] Wamitila, K. W. (2003). Kichocheo Cha Fasihi Simulizi na Andishi. Nairobi. Focus Publications Limited.

[12] Arege, T. (2013). Tunu ya ushairi. Nairobi: Oxford University Press.

[13] TUKI (1981). Kamusi sanifu ya Kiswahili Dar es Salaam.

[14] Kahigi K. K. (1994). Lugha Katika Vitabu Vya Watoto. Katika Kioo cha lugha: Jarida la Kiswahili, Isimu na Fasihi. Idara ya Kiswahili, Chuo Kikuu cha Dar es Salaam. Juzuu, Na. 1.

[15] Myers na Simms (1978). The Longman Dictionary of Poetic Terms: London, Longman. 
[16] Mbuvi, K. F. (2013). Mwongozo wa kidagaa kimemwozea, Nairobi: Target Publication Limited.

[17] Senkoro, F. E. M. K (1982). Fasihi. Dar es Salaam: Press and Publicity Centre.

[18] Wamitila (2008). Kazi ya fasihi: Msingi ya uchanganuzi wa fasihi. Phenix Limited, Nairobi.
[19] Kuhenga C. (1997). Tamathali za usemi, Dar es Salaam: Eat Africa. Literature Bureau.

[20] Abdulaziz M. H, (1979). Diwani ya Mashairi ya Muyaka. Nairobi: Kenya literature bureau. 